Article

\title{
The Right to the City in the Platform Age: Child-Friendly City and Smart City Premises in Contention
}

\author{
Shenja van der Graaf \\ imec-SMIT, Vrije Universiteit Brussel, Pleinlaan 9, 1050 Brussels, Belgium; shenja.vandergraaf@imec.be; \\ Tel.: +32-4705-09885
}

Received: 21 February 2020; Accepted: 26 May 2020; Published: 27 May 2020

\begin{abstract}
This article sought to develop a critical account of the ever-increasing role of ICTs in cities and urban governance discourses, captured by a growing interest to 'smarten up' our cities, for their inclusiveness of citizens more broadly, and that of children, in particular. In revisiting rights-based approaches, it gives particular attention to the (political) premises of two urban concepts, that is, child-friendly cities and smart cities. The focus here is on how these current concepts encompass and direct the make-up of children's relationship to the city, which brings the question to the fore of 'whose version is it?' A predominant provider's perspective and a normative discourse are revealed which seem to overlook emergent logics of children's social needs and experiences in the city. It is therefore proposed to revisit and revise our existing ideas, thus critiquing the current potential of the emerging 'rights-based' agendas in improving outcomes for children by urging cities to become child-friendly in their smart city ideals.
\end{abstract}

Keywords: children; citizens; participation; datafication; smart city; child-friendly city; human rights; right to the city; everyday life

\section{Introduction}

Today, our city life is no longer marked by us navigating landscapes of bricks and mortar, but also by algorithms and data [1]. This blurring between physical and digital boundaries of the city is supported by various technologies and more and more shaped by information and communication technologies (ICTs) such as platforms and services like Google that are progressively implicated in the structures shaping everyday life in the city. Captured by the momentum of the 'smart city' imaginary which denotes deep roots in, arguably, rather normative framings where technology plays a primary facilitating role and increasingly is said to underpin what it means to live in cities. Embedded into the systems and infrastructures that foster the built environment and governance dynamics, various manifestations can be detected-e.g., in patterns of consumption, socializing and service provision - that are said to, among others, reduce costs, improve insights in urban flows, spur innovation, enter new markets, and support sustainability goals [2-4]. The 'smart city' concept has generally been associated with "the intersection of data technologies and urban environments", while "the unique affordances of platforms are said to signal an evolution of the socio-technical relationship between citizens and cities" [5] (p. 116), what has been termed 'platform urbanism' [6,7]. Public and private entities (separately, and jointly) are incrementally tapping value from this composite of growing assets, such as via new service models, by addressing and reconsidering action modalities, interventions, and the policies impacting the everyday life of many. Furthermore, this multi-stakeholder urban ecosystem is reportedly becoming more powerful and complex, and can record, quantify, and process enormous volumes of data at this convergence of physical and digital spheres as many aspects of human lives are being monitored and rendered into datasets [8-10]. 
It is with our everyday encountering and interacting with technologies such as sensors, cameras, smartphones and so forth, that an abundance of digitised information about bodies, habits, preferences, social relationships and the like are being generated [11]. While some marvel at these developments, others point to the possible risks and detrimental effects for citizens and society at large. Albeit fragmented along disciplinary lines, concerns are particularly raised about 'datafication' and 'participation', such as the possible exploitation of data traces by other actors and agencies (often without people's knowledge or consent) [12], the ever-expanding laborious connections of automated processes and supporting platforms with other platforms [13], the delegation of decision-making and governance of algorithmic engines of urban infrastructures [14], the implications of an increasing complex multi-stakeholder ecosystem characterized by market and nonmarket relations for public service delivery [15], and the reinforcement of (urban) inequalities [16]. Thus, in order to grasp what is going on and what it means, critical attention in media and urban studies (and beyond) has largely shown a seeming data fetishization and the overlooking of human elements and agency in urban processes.

In today's climate to 'smarten up' our cities, popular and academic debates have intensified on precisely such concerns, warranting the investigation into the framing of citizen roles. Understanding citizens and having information about their needs, preferences, patterns and the like, is considered to facilitate the creation of sophisticated services and outcomes tailored to their needs as well as can contribute to city planning initiatives, the design and buildout of digital infrastructure [17-22]. Interestingly, the majority of smart city initiatives assert to be 'citizen-focused' or 'citizen-centric' which is, at the same time, arguably, being increasingly challenged by a data-centred discourse and focus on the collection of (intimate) information that can speak on behalf of citizens. Furthermore, a citizen-focused perspective alludes to including everyone, however, in practice, some groups are left behind. Children and youth are one such important group. In the literature, a call can be heard to improve services and outcomes to (better) fit the needs of children and youth [23-28]. Available research and initiatives, from European Network for Children Cities, to United Nations Children's Fund's (UNICEF) child-responsive urban planning, to Bernard van Leer's Urban95, to urban childhood studies, to children's digital literacy, insights have been produced that in/directly are indicative of how children act, move, and live in today's cities and which urban infrastructure and (ICTs) services they may find useful, yet there is still work to be done in improving the dynamics between a child-centered perspective and a children's perspective [29-32]. Furthermore, perhaps unsurprisingly, the framing of citizens in cities has sparked a renewed interest in the 'right to the city' [33-35], but also in these debates, children's rights deserve more vigorous consideration [36]. The right to the city "is not merely a right of access to what already exists, but a right to change it after our heart's desire" [37] (p. 939). It draws on "a new urban commons, a public sphere of active democratic participation" (p. 941) that is collective and inclusive.

This article seeks to contribute to the debate about the ever-increasing role of ICTs in cities and urban governance discourses for their inclusiveness of citizens more broadly, and that of children, in specific. Particular attention is given to the (political) premises of two urban concepts, that is, child-friendly cities and smart cities, thereby highlighting the materialization of child-centred rights-based approaches. The exploration primarily builds on several seminal studies (including bibliometric ones) that have been conducted on both research fields [29,38-49]. These works have rendered insights into the formal properties of and current developments in these knowledge domains. While the literature has documented on the importance to involve children in urban planning, particularly from a rights angle, in the smart city context this discussion has been largely absent, while increasingly a rights perspective can also be detected in that setting. The focus, however, is not on providing a literature review as such, but rather to draw out an agenda-supported framework at the intersection of the smart city and child-friendly premises. The research conducted and preliminary insights presented here have been gathered as part of a larger ongoing study on child care as a critical factor of child-friendly cities and, more recently, child care vis-à-vis digitalization as a second order outcome in smart cities [50]. In addition to a document analysis, a mixture of participatory and survey methods, have been deployed 
in six pilot cities (Bologna, Gyor, Kortrijk, Thessaloniki, Trento, Venice) across four countries (Belgium, Greece, Hungary and Italy) and involves children aged 3-11 and their parents [51]. Whereas this study does not represent a 'sample' as such, this exploration aims to be generalizable to the theoretical propositions-and consequently, provides a basis for analytical generalizations [52,53].

Against this backdrop, the article sets out to systematically address how the current dynamics materializing between child-friendly and smart city concepts encompass and direct the make-up of children's relationship to the city, and which brings the question of 'whose version is it?' to the fore. It is positioned to yield an agenda-based framework for cities to become 'smarter' about becoming (more) child-friendly in their smart city ideals. In doing so, first attention is given to the role of citizens, especially children in the city, thereby highlighting participation, datafication and rights. This is followed by the examination of the child-friendly and smart city premises in order to further unpack current perceptions and logics which foster children's relationship, or right to the city. The insights generated point to the issues at stake which undermine the current potential of the emerging 'rights-based' agendas in improving outcomes for children. This means that research with children to examine the current claims must be brought within in the critical project, so to connect better and operationalize child-friendly and smart city ideals. Finally, some pointers are provided that can serve as a framework to achieve this.

\section{Participation, Datafication and Rights}

Over the last decade or so, the smart city imaginary has become a fashionable theme within popular and academic discourse and entails a distinct set of rationalities $[39,40]$. Commonly, cities tend to use the term as a boosting mechanism and ICTs are put forward as a means to tackle complex urban issues, thereby accentuating pragmatic and functional aspects related to efficiency, safety and the like conjoined by questions and critiques about privacy, control and ownership [54]. Grappling with the rise of this 'smart city thinking' is said to be indicative of a fundamental shift associated with new consumptions patterns and technologies transforming both service delivery and people's lives in general. In understanding the influence of technological-driven innovations over the public sphere, played out in private, public, people dynamics, critical attention has particularly been given to address the pervasiveness of the gatekeeping that complex multi-stakeholder urban ecosystems make possible, the invisibility of that filtering and the lack of transparency [6]. A growing theorization and body of empirical evidence can be detected that concentrates on, especially, the intertwined streams of thought about participation and datafication.

\subsection{Participation}

The idea of participation is far from new, but it has become a gripping topic for public scrutiny in society. More recently, it has become an important term in developing a framework to understand how the changing media and communication environment enables or hinders participation in society. In fact, 'participation' has been conceptualized as "the state of being related to a larger whole" (The Merriam-Webster dictionary), and "the process or fact of sharing in an action, sentiment, etc.; (now esp.) active involvement in a matter or event, esp. one in which the outcome directly affects those taking part." (the Oxford English Dictionary). The term holds that it is about taking part in something, it promotes certain interests and is never a fully individual act, as such reflecting a more normative agenda.

"People act in all kinds of ways, for better or for worse, and generally society considers that a matter of individual freedom. But when people participate in something, society tends to judge whether such participation is beneficial to the participants and/or the wider public, and it may provide public funding or other institutional support." [55] (p. 24).

In this view, today's media environment is said to reshape the 'opportunity structures' by which people can participate in an increasingly mediatized society [56]. The term has gained renewed momentum as evidence of the so-called 'participatory turn' associated with the Web 2.0, offering 
users an easy-to-use creative infrastructure to actively engage in digital development practices [57]. In this way, users-though not all, and not equally-are invited to produce, alter, and share digital content (or, data) as well as also attract their own public on firm-hosted platforms. The processes of participation - and, more widely, of democracy-are thus increasingly shaped by ICTs. However, not everyone participates, and not all participation is mediated. In unravelling how this changing environment permits or hinders modes, or 'opportunities' of participation, the literature accentuates an ever-increasing 'mediatized' society [58] which "all parts of society being reconfigured according to "media logics" [17] (p. 175). For example, facilitated and dynamically built in the logic of so-called platform companies like Facebook, Google and Uber, such practices are indicative of rapidly evolving, yet, often subtle, relationships of collaboration among users but also with other stakeholders across public and private firm, and platform boundaries (see 'multisided platforms' in [59] and 'platformization' in [60]). This, arguably, has become the dominant and common online organizational form for platform companies to describe their role in the market and their services towards their stakeholders including cities (e.g., Google's social navigation app Waze), associated with a strong neoliberal ethos—like the ongoing 'corporatization of city services' [61]—underpinning all kinds of (meta)data appropriations [62].

\subsection{Datafication}

A key aspect of the functioning of ICTs is that they generate, process, and extract value underpinned by vastly granular and indexical data streams (e.g., people, households, areas). This-what has been termed-'datafication' is strongly associated with the smart city framework by the investigation of data-driven correlations, such as evidence of behavior-spatial tracking which is used to make inferences about affiliations, participations and predispositions. These practices bring all kinds of ethical issues to the fore, such as about privacy, data-and geoveillance, profiling, social sorting, nudging, and anticipatory governance [18]. A strong focus can, therefore, be distilled that is increasingly attuned to the ways in which the materialities of various data regimes-such as 'socio-spatially' by changed, or novel needs and usage patterns of the 'networked social' in public space [63]—are played out in society and the in/direct impact on people's everyday lives.

In other words, there are significant ramifications of turning people into 'data assemblages', where data seem to speak for themselves and override people's rights to speak for themselves. These practices affect adults as well as children. While children have since long been subjected to monitoring practices (e.g., 'government of childhood' [64]), in today's 'datafied environment' [65] children-like adults-have also become positioned as consumers of products and services as well as producers of data [66]. Triggered by the perils and promise of empowerment of ICTs, a plurality of approaches towards participation can be detected and from which no clear-cut theorization or definition can be distilled, or how participation should be examined and evaluated $[67,68]$. Participation in urban planning can be said to have largely spurred from protests against a proposed project [69]. In the context of children, the idea of them shaping their own environment has received attention from different disciplines, including but not limited to psychology, sociology, historical anthropology and human geography, spanning several decades—such as the Growing up in Cities (GUIC) project (1976), supported by UNESCO, was appreciated for making the relation between urban conditions and children's well-being apparent. In the 1980s and 1990s childhood-related research peaked, focusing on various issues, but a particular interest could be detected on the relation between space and child development. While participation in general may not be unequivocal, for children it is perhaps even more complex. In the past, children's participation has had the tendency to be about playful activities to educate children about political processes. Today, it is more about the concept of citizenship which has become inseparably linked to the discourse about participation; thus, to what extent is the child participating in urban life? In essence, it is about to what extent children and young people are viewed as full citizens, partial citizens, citizens-to-be, and so forth [70], thereby also drawing attention to various participations, such as based on citizenship (e.g., youth councils), consultation (e.g., youth with 
diabetes), and the relationship to adults (e.g., child vs. adult-initiated practices that share decisions with adults) [71,72].

When turning to the role of the citizen in the smart city agenda increasingly underpinned by the claim to be 'citizen-focused' or 'citizen-centric', research has shown that the citizen-regardless of being an adult or child-is understood, among others, as a user, surveilled subject, data point, and a targeted consumer, underscoring citizens can be directed, nudged and controlled [73-75]. In other words, "citizens most often occupy non-participatory, consumer or tokenistic positions and are framed within political discourses of stewardship, technocracy, paternalism and the market, rather than being active, engaged participants where smart city initiatives are conceived in terms of rights, citizenship, the public good, and the urban commons." [18] (p. 11).

In this view, a disconnect can be detected between the dynamics grounding in the common good and rights perspectives, and (individual) responsibilization of citizens associated with a neoliberal stance. Even when more participatory mechanisms are at work (e.g., Living Labs, citizen science), these are said to merit the 'project', and not the 'labour', of smart city ideals advancing mostly economic objectives [76]. Critical attention in media and urban studies is therefore increasingly directed towards the examination of the role of, particularly, platforms as these are indicative of an advancement of the socio-technical relationship between citizens and cities $[5,15,77]$, and for which a public oversight over these developments and their implications—-such as increased choice yet with less meaningful participation-are lacking. In these studies, the citizen as 'object' seems to be downplayed in favor of investigating the process of 'usership' (see 'citizenship' in [73,78]).

\subsection{Rights}

As the dust is now settling somewhat, a renewed interest in people's agency is gaining ascendancy by focusing on rights. In media studies this can be evidenced in the advocacy of digital rights, particularly underpinned by the 'Principles for a Contract for the Web' initiative that was launched in November 2018.

"The web was designed to bring people together and make knowledge freely available. Everyone has a role to play to ensure the web serves humanity. By committing to the following principles, governments, companies and citizens around the world can help protect the open web as a public good and a basic right for everyone" [79].

This initiative elaborates on a 2014 'Web We Want' campaign which marked the 25th anniversary of the World Wide Web (WWW), by Tim Berners-Lee and the WWW Foundation for a bill of rights to ensure the independence of the Internet and to protect the rights of individuals online. To date, it remains to be seen if this effort will lead to a universal and full contract that will hold each party accountable to contribute to building and sustaining an accessible, open and free web that serves humanity and is a public good for all. This and other initiatives are well-intentioned but as digital rights are, so far, indefinite it is mostly national laws, and typically pre-digital legislation, that has to grapple with rights of Internet users. What seems equivocal is that digital rights should be a basic human right so as to safeguard autonomous 'man' from interference ensuring self-determination, free thinking, privacy preservation inasmuch on the condition of refraining from inflicting harm on others $[45,80]$.

There are, in fact, numerous ways of conceptualizing rights; how a right is defined, the form it takes, and how it is determined who should have a right relies on political and legal philosophy as well as a mere practical stance. For example, is a digital right a liberty right, a legal right or a moral right, a prima facie right or an absolute right, or if a mixture, are such rights commensurable? [81]. Furthermore, a recent debate among scholars of human rights history seeks to account for the genesis and (dis/continuous) span of contemporary human rights practice [48]. The so-called 'rights turn' can perhaps be understood in this context, as it sheds light onto discussions about more intellectual and activist or fundamental approaches towards human rights [82]. In terms of a turn to digital rights Livingstone and Third [83] subscribe to a more imaginative and activist vision as "it is precisely in the 
absence of 'lived' rights that an idealistic vision-a manifesto for the digital age-is most needed." (p. 658). Turning to the literature on the rather ambiguous concept of 'the right to the city', which is derived from Lefebvre (1968) [33], insufficient insights are available into what kind of right(s) the right to the city entails. However, increasingly, the intellectual stance engages with what the right to the city may mean for urban politics in how it can be deployed to reframe such politics, and in a more activist way, to counteract certain policies [84]. More recently, these rights debates have been reinvigorated in the context of smart cities, particularly associated with the datafication trajectory as outlined above [38,85-87]. Issues including the right to appropriation in the smart city and the right to understand what data are being produced about citizens and places have been investigated and debates seem to allude to instigate a unitary right, that is, a right to social justice. Furthermore, the term of technological sovereignty can be heard in the reorientation of the city of Barcelona, denoting that technology should serve and be local resident-orientated and be owned as a commons [88,89], and which is considered to provide a "different form of smart citizenship, one that seems much more grounded in the hopes and politics of the 'right to the city' agenda" [18] (p. 20).

The interest in a rights-based approach concerning both the digital and the city demonstrates, arguably, increasingly overlapping aspirations and claims about, among others, equality, social in/exclusion, citizenship, privacy, safety, and public space. In fact, these and other issues seem even more pressing today, yet, which (political) direction to go is contested and ongoing. Particularly, where children are concerned, and which are underrepresented in emerging rights-based trajectories of digital and urban development [26,90-93]. Having said this, a child-focused rights trajectory-for those under age 18-emerged from the United Nations (UN) Convention on the Rights of the Child (CRC), adopted by the General Assembly in 1989, which in hindsight, coincided with the beginning of the Internet [44]. In 54 articles, it spells out many rights underpinned by the 'Ps' of protection, provision and participation rights. Even if being the most widely ratified human rights treaty in the history of the UN, it is not without its challenges. One debate focuses on the figure of the child, and what their 'status' is (often vis-à-vis adults), such as 'sub-human' or 'not-yet-fully human', and subsequently, whether they need their own set of rights that differ from those of adults $[82,94]$. Another debate draws attention to the issue of power which is said to be often downplayed when it comes to children's rights. The 'power of rights' may be easily overlooked, for example, as Alderson points out when it comes to, "participation rights, linked to freedom and self-determination, might be respected as the most adult-like set of rights, but it is too often reduced into Article 12, 'The child's right to express views freely in all matters affecting the child', with less attention to whether children are actually heard or their views are acted on seriously. Children may be presented with quasi-shopping lists, and asked what more resources and opportunities they would like to enjoy empty of political power" [90] (p. 84).

Notwithstanding this criticism that alludes to rights and their claims against injustice and accountability, the articles related to participation have generally been seen as a radical addition, particularly, by governments as many tend to have accepted their responsibility supported by the principles of non-discrimination, best interest, survival and development of the child, and now also participation [95]. How such principles are played out and rights realized, however, is up to governments (and their citizens) [96]. With the more recent focus on 'participation' of citizens, including children, in urban governance-associated thus with the environmental movement in the 1970s of advocacy planning and citizen participation as well as the growing scholarly interest in the 'right to the city' - the conditions for children's participation in urban governance has shifted and highlights their rights 'to' cities and 'in' cities. Participation is about reciprocal responsibilities and collective aspects, "children's right to participate in decision-making processes that shape cities is as fundamental as their right to individual access to city resources. This right implies a need to empower children to become partners in deliberative democratic practices, teaching them skills of collaboration and empathy, and imparting to them recognition of interdependence as both an inescapable fact and a positive principle" [95] (p. 758). 
Against the backdrop of these new conditions, the current dynamics materializing between the smart city and child-friendly ideals are assessed and the way these urban concepts underpin children's relationship to the city.

\section{Intersections between Child-Friendly Cities and Smart Cities}

The urban concepts of child-friendly cities (associated with children) and smart cities (associated with technologies, such as platforms) have both been shaped in a literature that spans several decades, respectively the former from the 1990s and, the latter, the 1980s. While they have to be appreciated for their different development contexts and histories, each in their own way, carry out the work of political ideas and have become, arguably, a prescriptive mix promoted by public authorities and private entities such as planners. In offering a synthetic analysis of their dynamics, competing and complimentary logics relating to the (emerging) agenda on children's rights and, urban spatiality more specifically, in the 'smart city' age can be revealed.

\subsection{Child-Friendly Cities}

The Child Friendly Cities initiative (CFC) builds on a renewed and growing interest in the 'right to the city' [36,97], occurring in the wake of new normative frameworks and action plans formulated for human rights by the UN-Habitat and UNICEF. It launched in 1996 and ever since offers guidelines for how municipal governments (or, cities) can realize and integrate a rights-based perspective locally into all services and decision-making processes that impact children [44]. Putting a rights-based approach forward meant directing the policy focus away from 'problems and deficits' and see children-individually and collectively_as competent and meaningful participants in shaping the urban environment, so subscribing to the rights 'in' and 'to' the city perspective. Yet, what is a child-friendly city? UNICEF stresses the commitment of local governance for children to realize their rights, which in practice means that a CFC is a city where children, among others, "experience quality, inclusive and participatory education and skills development," "express their opinions and influence decisions that affect them," "participate in family, cultural, city/community and social life,", and "meet friends and have places to play and enjoy themselves" [46]. However, there is no single definition of what a CFC is or should be, or that this, in reality, is even feasible due to perpetual changes in local and global landscapes as well as increasingly profit-oriented urban markets [98] (see CFC-related 'typology of children's roles' in [99]).

However, guidelines do exist in support of developing a child-friendly city. The CFC discerns nine building blocks that centre on children's participation, a child-friendly legal framework, a city-wide children's rights strategy, a children's budget, a children's rights unit or coordinating mechanism, a child impact assessment and evaluation, a regular State of the City's Children report, a plan for making children's rights known, and support for independent advocacy for children [100]. The goal is thus to offer a structure of governance that is responsive to children's rights and seems-without much explicit reference to aspects of place in children's lives-to have essentially become a rather procedural and organizational concept.

In more practical terms, many city governments increasingly find the 'child-friendliness' of their cities important, yet have been slow-going to establish (any, and structurally) participatory processes with children $[29,98]$. High-income countries tend to be indicative of CFC programs that tend to promote children's freedoms and quality of physical areas available in neighborhoods, while in low-income countries the focus remains on addressing immediate issues, such as risk exposure. More specifically, in the literature on CFC, particular attention has been given to mobility and freedom which are fundamental rights of children. It has been shown that children's independent mobility to explore their urban environments has decreased by far for reasons related to risk aversion such as parental perceptions of (traffic) safety and stranger danger as well as a decrease in nearby destinations like the corner store $[97,101,102]$. In addition, not much insight is available on the equality (think adults) and ways children may use and experience more spontaneous encounters with amenities of public 
space. Insights are lacking how CFC policies and practices enable and facilitate (emergent) socio-digital transformations that reveal the relation between social life and public space engagement, underpinning the institutionalization of children's rights to the city. Thus, CFC seem to portray (spatial) qualities such as proximity, walkability, intergenerational use, public space, independent mobility, and connectivity, yet, it seems not to resonate much with ongoing digital transformations including those associated with children's (changing) sociability in shaping, connecting and experiencing their on/offline everyday lives, especially in cities [103-106]. In addition, there is a tendency of children's spatial and social exclusion in urban environments [84]. Often, this 'marginalization' occurs by normatively marking or differing public spaces in relation to adult space; children "are excluded from the dominant "adult" public space through controls and rules, afforded only with "leftover" or "token" spaces which are usually not sufficient to their needs" [2] (p. 111). Such a restrictive approach may also affect the relation of their everyday (social) life and public space engagement, yet the ways in which ICTs may play a role-isolation, interaction and so forth-remains unclear.

\subsection{Smart Cities}

Turning then to the pervasive urban concept of smart city, it is exactly 'technology' that gets highlighted. The term appeared in the 1980s alongside terms like intelligent and cyber city, pointing to a trajectory of urban change associated with ICTs and urban systems innovations. From the 2000s, however, the term smart city took flight and elaborates a planning and development paradigm which "technological bases (telecoms and virtuality) were enriched with various forms of networking, social intelligence and innovative IT functionalities, that made it possible to describe the urban space as intelligent" [40] (p. 20). More specifically, increasingly the smart city concept is associated with terms like algorithms and artificial intelligence, and considered paramount to the governance, operations, experience, navigation and so forth of cities. This is said to underpin the (changing) basic tenets of what it means to live in cities associated with, arguably, how public space is 'translated' into 'code', and the way 'code' is seen to 'reshape' the urban space, or society [107]. In this stream of thought, the potential of the conceptual and technological status quo can be framed, providing a salient illustration of how information and knowledge is represented and configured between technology such as platforms and the urban $[6,108]$.

While the smart city imaginary has become a subject matter within the literature including in media studies, as discussed earlier, its meaning and rationalities are diverse $[109,110]$. The focus of the smart city framework, arguably, seems to concern pragmatic and functional aspects, paralleled by questions and critiques such as about privacy, as well as about rather solutionist visions that are insufficient to remedy such pressing urban complexities. Interestingly, it being seen as a pillar supporting the planning and development paradigm, the smart city concept does not provide a clear, if any, spatial vision instead it puts a more thematic-orientation forward such as administration, citizen engagement, the environment, public safety, and transportation, thereby strongly advocating 'open data' [89]. Furthermore, technology-driven and human-driven, top-down and bottom-up planning, and collective intelligence and data-driven intelligence are generally seen as the structuring axes underpinning the smart city literature. Unsurprisingly, the physical manifestations and spatial characteristics cannot be easily distilled.

From a social stance, however, the literature does point out that technological innovation and prosperity cannot fully succeed without citizens, communities and social capital, more broadly. Concepts like co-creation and participatory city-making (or, hackable city; [111]) are seeming mantras to stress the (implied) role of the citizens-presumably, having some ability and understanding of using technology -in relation to the smart city vision to improve the cities' capacity to learn, transform, and innovate [112]. Citizen participation is also linked, as enactment, to the 'right to the city' notion, which is evoked in the smart city discourse to examine participation-derivatives such as participatory city-making and its translation of the right to the city into practice [113,114]. However, increasingly, the smart city rhetoric can be questioned for concealing inequality and to work as a 'boosting mechanism' 
where the 'smart city' is a business model rather than serving a model of social justice. In fact, the smart city premise is foremost managerial and pragmatic, embedded deeply in the neo-liberal ethos [110]. Furthermore, questions are raised about the growing control of (local) government over its citizens, such as in terms of data/surveillance [111] and also the increasingly complex ('black box') public-private platform-based ecosystem, or 'platform urbanism' (for example, the Connected Citizens Program by Alphabet/Google/Waze that collaborates with many cities world-wide via its social navigation application [6,115]. In this light, a call can be heard towards developing more 'humane' "(in the sense of the good characteristics of humans) cities, where planning is focused on citizens' wishes, interests and needs" [21] (p. 91).

The smart city concept gives no specific attention to children. Citizen participation and engagement seem primarily focused on older generations. However, a smart city outlook can be combined with the CFC premise, but it is often not made explicit. For example, the city of Antwerp (Belgium) aspires to be(come) a smart city and its strategy focuses on industry 4.0, smart logistics and citizen-focused initiatives (air quality and mobility). Nowhere are children mentioned in these vision-related documents. At the same time, Antwerp advocates to be a child-friendly city yet this is, to date, not part of the mainstream administration (and, thus not fully documented). For example, 'place space web' is a (spatial and participatory) approach to develop playgrounds. It operates on the neighborhood level and draws on open data (e.g., GIS), thereby (mostly) taking children's demands and responses into account in planning and readjusting the public space as well as the routes that connect them. In addition, due to the shortage of space 'street reclaiming' can also be seen, such as a 'school street' and 'garden street' [116]. In line with this, mobility remains an obstacle in making the city more child-friendly as, for example, initiatives to reduce the impact of cars (on space, on pollution etc.), such as circulation planning, is currently politically a no-go.

The challenging context of improving affordable child care can also be seen to operate on bringing the smart city and CFC ideals closer [49].

"Childcare is also a critical factor of child-friendly cities, to enable women to carry on working. A smart city needs digitalisation not just for the technology, but also for this fact. The fact is that the programme for the digitalisation in Stockholm now takes a starting point, not in the technology but in the fact that fewer people have to pay for many more people" [117].

In particular, public service delivery towards informal child care can be seen to emerge aimed at combining digital tools with collective intelligence models and participatory methods so as to better cope with the challenges of, particularly, restricted access to childcare, after-school activities and learning opportunities. While a growing interest can be detected in the contribution of community-based initiatives towards informal child care transitions systematic, quantitative, and comparative assessments of their potential impact across different social, economic and political dimensions are scarce. In seeking to wed child-friendly and smart city perspectives in involving not only parents but also children themselves, ICTs for both parents and children are deployed-for different purposes, such as an app for parents to organize informal/parent-led child care within the neighborhood and supported by the local administration in providing, e.g., toys, or for children as educational and connecting device during the informal day care session. This is also part of a more recent call by UNICEF for child-responsive urban planning which, in addition to principles such as public amenities, public spaces, transportation systems and integrated water and sanitation systems, now also includes data and ICT networks "to ensure digital connectivity for children and the community, to universally accessible, affordable, safe and reliable information and communication" [29] (p. 5). While the study is ongoing at six pilot sites in Belgium, Greece, Hungary and Italy, preliminary findings are indicative of the importance to involve children themselves and monitor from their stance, their meaning-making and change in experience between formal and informal child care as a gap becomes apparent between e.g., needs and expectations between parents and children [50]. Such insights offer a starting point to get to know how they act, move, and live in cities more broadly and which infrastructure, facilities, and services 
including ICTs they consider important and how to design and implement sophisticated applications and services for that purpose.

\section{Children and the City at Play}

For urbanization to be long-lasting and sustainable, it should be so for all current and future citizens, highlighting a right to social justice. One important group concerns children which are underrepresented in emerging rights-based trajectories of digital and urban development. Putting them central in urban planning, however, is not so easy. Not only are various complex issues at play, such as the speed of urbanization, the capacity needed, trade-offs made amongst sectors and investment costs vis-à-vis urban sprawl, but as pointed out also developing and delivering on a citizen-centered approach more broadly; is not clear-cut. In aiming to understand better the dynamics between the urban premises of smart cities and child-friendly cities attention was drawn to their respective politics of pragmatic and functional aspects, and procedural and organizational aspects. The benefits of the smart city 'ICTs-orientation' are somewhat used in the CFC efforts, yet, they tend not to be directly child-facing by taking into account their (digital) engagement with their own socio-spatial geographies in the current make up of their everyday lives. The role of children and their rights 'in' and 'to' the city are unstructured and not (fully) integrated in the administration.

Thereby variances in meaning-making and experiencing their city and their (changing) social lives in it or, arguably, 'children's citizenships' such as being a 'datafied child'-increasingly also associated with the commodification and privatization of space, and the neoliberal project more generally-are not systematically investigated or part of the discourse [118]. Rather, contemporary debates that focus on the ubiquity of technology-increasingly associated with platforms-in society have produced critical insights in the hopes and the perils of processes of 'usership' in the city. While studying digital traces has made citizens visible in new ways, it also tends to obscure [cf. 'audience logics' in [119] and 'human/e cities' in [21,120]. With novel logics of public space engagement emerging, it is paramount to systematically examine the meaning-making and experience of citizens in public space usage and the role technology can play. Without rekindling the investigation of their engagement with ICTs and the relation between social life and space, it becomes increasingly complex to check and qualify claims giving rise to blind spots involved in elements of participation and datafication. This goes particularly for children. Thus, while technology plays an important role in children's everyday lives, very little is known-from their own perspective-about their (changing) needs, behaviors and experiences in how they participate and create their own spaces in their encounters with public places and the way their socialization processes are therein embedded [121,122]. More specifically, children are increasingly marginalized, even 'invisible' in techno-oriented urban planning and development frameworks, without much consideration for their own experience and meaning-making, (social) needs, or voice in decision-making.

Furthermore, the child remains a 'rigid and slippery category' associated with the problematic of exceptionalism which almost always means 'not being part of' the broader frame or agenda. Not only are children foremost viewed as vulnerable and their social needs but also, especially, their voice tends to be overlooked by adult discourse, values and operations and (political) premise that have become a prescriptive mix with likely long-term implications for children's well-being in tomorrow's cities. Also, the focus tends to be on 'space' whereas both smart city and CFC ideals seem to be grounded in procedures and management. Yet, when 'space' is concerned, also here a predominant provider's perspective and a normative discourse associated with adult labels, such as of risk, still seems to overtake children's benefits in having overall more freedom to 'go out and about' and be truly part of shaping not only their everyday public space but also the city of their future. Accepting this, a double articulation of a purported exclusion of children seems to occur. In the contemporary data-centered discourse citizens' voices are increasingly said to be taken over by 'data speaking for them'. When learning about children's urban requirements not only data is said to 'take over', but such practices 
tend to heavily rely on an adult perspective that can be seen to draw out general assumptions on what children supposedly consider important and how they may behave.

\section{Conclusions}

In exploring the dynamics between the concepts of rights and children underpinned by the competing and complimentary logics of the child-friendly city and smart city premises, the argument was made that (emerging) rights-based approaches are not systematically underpinned by child-centered theory. Rather they are abstract (legal) frameworks and structures for governance, while children's rights ideally should facilitate for, at minimum, their voice to be heard and count. Yet, now with the tremendous focus on exploring metaprocesses such as datafication children's voices may even be less 'heard' as 'data assemblages' generated by—private and public—-datafication and dataveillance are said to actually 'speak on their behalf' seemingly side-lining participatory ideals even further. In this way, children's social and spatial exclusion in urban environments only widens, resulting in, for example, deprivation of a sense of belonging to the (social) networks of their neighborhood at a time where the fundamental nature of community seems to be changing as social media platforms meld with in-person connectivity.

Thus, with the current smart city trend and ongoing CFC efforts the social, everyday and economic tapestries of the city, technology and the child should be brought into dialogue. An important means to achieve this is by drawing out a value network of 'power' in managing the city so as to understand who is influencing and who is in charge. This is then the point of departure to develop a multi-stakeholder approach along the dimensions of an evidence and data-based trajectory that involves children and communities within the environments where they live and grow, and supported by change in policy, particularly, concerning urban planning and financing streams. Such ingredients lay at the basis that allows us to revisit and revise our ideas of children's public space engagement in their re/connections with people and places around them-both in-person and digitally—so as to ameliorate the current potential of the emerging 'rights-based' agendas in improving outcomes for children. In other words, where cities are 'smart' about becoming child-friendly in their smart city ideals. Only in doing so, the question can be answered how current urban concepts encompass and direct the make-up of the shifting 'voice' of children in the city and make it their version.

Funding: This research has received funding from the European Union's Horizon 2020 CAPS Topic: ICT-11-2017, Type of action: IA, Grant agreement No. 780783.

Conflicts of Interest: The author declares no conflict of interest.

\section{References}

1. Graham, M. Regulate, replicate, and resist-The conjunctural geographies of platform urbanism. Urban Geogr. 2020. [CrossRef]

2. Menezes, M.; Arvanitidis, P.; Smaniotto Costa, C.; Weinstein, Z. Teenagers' Perception of Public Spaces and Their Practices in ICTs Uses. In CyberParks_-The Interface between People, Places and Technology; Smaniotto Costa, C., Ed.; Lecture Notes in Computer Science; Springer: Cham, Germany, 2019; Volume 11380, pp. 109-119.

3. Kitchin, R.; Perng, S.Y. Code and the City; Routledge: London, UK, 2016.

4. De Falco, S.E.; Renzi, A.; Orlando, B.; Cucari, N. Open collaborative innovation and digital platforms. Prod. Plan. Control 2017, 28, 1344-1353. [CrossRef]

5. Lee, A.; MacKenzie, A.; Smith, G.J.D.; Box, P. Mapping Platform Urbanism: Charting the Nuance of the Platform Pivot. Urban Plan. 2020, 5, 116-128. [CrossRef]

6. Van Der Graaf, S.; Ballon, P. Navigating platform urbanism. Technol. Forecast. Soc. Chang. 2019, 142, 364-372. [CrossRef]

7. Barns, S. Platform Urbanism: Negotiating Platform Ecosystems in Connected Cities; Palgrave Macmillan: Singapore, 2020. 
8. Parker, G.G.; Van Alstyne, M.W.; Choudary, S.P. Platform Revolution: How Networked Markets Are Transforming the Economy and How to Make Them Work for You; W.W. Norton \& Company: New York, NY, USA, 2017.

9. Moazed, A. Platform Business Model-Definition | What Is it? | Explanation. Platform Innovation//Blog. Applico, 1 May 2016. Available online: https://www.applicoinc.com/blog/what-is-a-platform-businessmodel/ (accessed on 11 April 2020).

10. Cusumano, M.A.; Gawer, A.; Yoffie, D.B. The Business of Platforms: Strategy in the Age of Digital Competition, Innovation, and Power; Harper Business: New York, NY, USA, 2019.

11. Lupton, D. How do data come to matter? Living and becoming with personal data. Big Data Soc. 2018, 1-11. [CrossRef]

12. Couldry, N.; Mejias, U.A. The Costs of Connection: How Data is Colonizing Human Life and Appropriating It for Capitalism; Stanford University Press: Stanford, CA, USA, 2019.

13. Nieborg, D.; Helmond, A. The political economy of Facebook's platformization in the mobile ecosystem: Facebook Messenger as a platform instance. Mediacult. Soc. 2019, 41, 196-218. [CrossRef]

14. Zambonelli, F.; Salim, F.D.; Loke, S.; De Meuter, W.; Kanhere, S.S. Algorithmic Governance in Smart Cities: The Conundrum and the Potential of Pervasive Computing Solutions. IEEE Technol. Soc. Mag. 2018, 37, 80-87. [CrossRef]

15. Van Der Graaf, S. In Waze We Trust: Algorithmic Governance of the Public Sphere. Media Commun. 2018, 6, 153-162. [CrossRef]

16. Ash, J.; Kitchin, R.; Leszczynski, A. Digital turn, digital geographies? Prog. Hum. Geogr. 2018, 42, $25-43$. [CrossRef]

17. Livingstone, S. Audiences in an Age of Datafication: Critical Questions for Media Research. Telev. New Media 2019, 20, 170-183. [CrossRef]

18. Kitchin, R.; Cardullo, P.; Di Feliciantonio, C. Citizenship, Justice and the Right to the Smart City. In The Right to the Smart City; Emerald Publishing Limited: Bingley, UK, 2018. [CrossRef]

19. Couldry, N.; Yu, J. Deconstructing datafication's brave new world. New Media Soc. 2018, 20, 4473-4491. [CrossRef]

20. Joss, S.; Cook, M.; Dayot, Y. Smart Cities: Towards a New Citizenship Regime? A Discourse Analysis of the British Smart City Standard. J. Urban Technol. 2017, 24, 29-49. [CrossRef]

21. Almeida, V.; Doneda, D.C.M.; Da Costa, E.M. Humane Smart Cities: The Need for Governance. IEEE Internet Comput. 2018, 22, 91-95. [CrossRef]

22. Mattern, S. Code and Clay, Data and Dirt: Five Thousand Years of Urban Media; University of Minnesota Press: Minneapolis, MN, USA; London, UK, 2017.

23. Hening, S. Child- and youth-friendly cities: How does and can crowdmapping support their development? A case study using OpenStreetMap in the Austrian City of Salzburg. Articulo. J. Urban Res. 2019. [CrossRef]

24. Bollig, S.; Millei, Z. Spaces of early childhood: Spatial approaches in research on early childhood education and care. J. Pedagog. 2018, 9, 5-20. [CrossRef]

25. Bishop, K.; Corkery, L. (Eds.) Beyond Playgrounds and Skateparks: Designing for Kids in the City; Routledge Press: London, UK, 2017.

26. Childress, H. Teenagers, Territory and the Appropriation of Space. Childhood 2004, 11, 195-205. [CrossRef]

27. Travlou, P.; Owens, P.E.; Thompson, C.W.; Maxwell, L. Place mapping with teenagers: Locating their territories and documenting their experience of the public realm. Child. Geogr. 2008, 6, 309-326. [CrossRef]

28. Hening, S. Smart Cities Need Smart Citizens, but What about Smart Children? In Proceedings of the REAL CORP 2014, Vienna, Austria, 21-23 May 2014; Schrenk, M., Popvich, V., Zeile, P., Elisei, P., Eds.; 2014; pp. 553-561.

29. Aerts, J. Shaping Urbanization for Children. A Handbook on Child-Responsive Urban Planning; United Nations Children's Fund (UNICEF): New York, NY, USA, 2018; ISBN 978-92-806-4960-4.

30. Harris, P.; Manatakis, H. Children as Citizens: Engaging with the Child's Voice in Educational Settings; Routledge: London, UK, 2013.

31. Björklid, P. Child-Friendly Cities-Sustainable Cities? A child-centred perspective and the child's perspective. In Environment, Health and Sustainable Development. Advances in People-Environment Studies; Abdel-Hadi, A., Tolba, M., Soliman, S., Eds.; Hogrefe: Göttingen, Germany, 2010; Volume 1, pp. 73-86. 
32. 880 Cities. Building Better Cities with Young Children \& Families. Bernard Van Leer Foundation, 2017. Available online: https://bernardvanleer.org/app/uploads/2017/10/BvLF-8-80-Cities-Report-Final.pdf (accessed on 7 April 2020).

33. Lefebvre, H. Le Droit à la Ville; SEUIL: Paris, France, 1968.

34. Attoh, K.A. What kind of right is the right to the city? Prog. Hum. Geogr. 2011, 35, 669-685. [CrossRef]

35. Cardullo, P.; Di Feliciantonio, C.; Kitchin, R. (Eds.) The Right to the Smart City; Emerald Publishing Limited: Bingley, UK, 2019.

36. Chawla, L.; Van Vliet, W. Children's rights to child-friendly cities. In Handbook of Children's Rights; Ruck, M.D., Peterson-Badali, M., Freeman, M., Eds.; Routledge: New York, NY, USA, 2017; pp. 533-549.

37. Harvey, D. The right to the city. Int. J. Urban Reg. Res. 2003, 27, 939-941. [CrossRef]

38. Shaw, J.; Graham, M. An informational right to the city? Code, content, control, and the urbanization of information. Antipode 2017, 49, 907-927. [CrossRef]

39. Mora, L.; Deakin, M. Untangling Smart Cities: From Utopian Dreams to Innovation Systems for a Technology-Enabled Urban Sustainability; Elsevier: Amsterdam, The Netherlands, 2019.

40. Komninos, N.; Mora, L. Exploring the big picture of smart city research. Sci. Reg. Ital. J. Reg. Sci. 2018, 1, 15-38.

41. Gandy, O.; Nemorin, S. Toward a political economy of nudge: Smart city variations. Inf. Commun. Soc. 2019, 22, 2112-2126. [CrossRef]

42. Zhao, L.; Tang, Z.-Y.; Zou, X. Mapping the knowledge domain of smart-city research: A bibliometric and scientometric analysis. Sustainability 2019, 11, 6648. [CrossRef]

43. Ruck, M.D.; Peterson-Badali, M.; Freeman, M. (Eds.) Handbook of Children's Rights; Routledge: New York, NY, USA, 2017.

44. Convention on the Rights of the Child. Available online: https://www.ohchr.org/en/professionalinterest/ pages/crc.aspx (accessed on 21 February 2020).

45. Universal Declaration of Human Rights (UDHR). Available online: http://www.un.org/en/universaldeclaration-human-rights/index.html (accessed on 16 February 2020).

46. What Is the Child Friendly Initiative? Available online: https://childfriendlycities.org/what-is-the-childfriendly-cities-initiative/ (accessed on 10 February 2020).

47. Brake, E.; Ferguson, L. (Eds.) Philosophical Foundations of Children's and Family Law; Oxford University Press: Oxford, UK, 2018.

48. McCrudden, C. Human Rights Histories. Oxf. J. Leg. Stud. 2015, 35, 179-212. [CrossRef]

49. National Institute of Urban Affairs. Compendium of Best Practices of Child Friendly Cities. Bernard Van Leer Foundation.: Den Haag, The Netherlands, 2017. Available online: https://bernardvanleer.org/app/uploads/ 2017/10/Compendium_of_Best_Practices_of_Child_Friendly_Cities_2017.pdf (accessed on 10 April 2020).

50. Van der Graaf, S.; Veeckman, C. (Eds.) The Sharing Economy as a Path to Government Innovation; Technology Innovation Management (TIM) Review: Ottawa, ON, Canada, 2020.

51. Families_Share. Available online: https://families-share.eu/ (accessed on 11 April 2020).

52. Bryman, A. Social Research Methods; Oxford University Press: Oxford, UK, 2012.

53. Snyder, H. Literature review as a research methodology: An overview and guideline. J. Bus. Res. 2019, 104, 333-339. [CrossRef]

54. Mosco, V. The Smart City in a Digital World; Emerald Publishing: Bingley, UK, 2019.

55. Livingstone, S. The Participation Paradigm in Audience Research. Commun. Rev. 2013, 16, 21-30. [CrossRef]

56. Cammaerts, B. Protest Logics and the Mediation Opportunity Structure. Eur. J. Commun. 2012, 27, 117-134. [CrossRef]

57. Van der Graaf, S. ComMODify! Mod Development at the Crossroads of Commerce and Community; Palgrave Macmillan: Cham, Germany, 2018.

58. Couldry, N.; Hepp, A. The Mediated Construction of Reality; Polity Press: Cambridge, UK, 2017.

59. Hagiu, A. Strategic decisions for multisided platforms. MIT Sloan Manag. Rev. 2014, 55, 71-80.

60. Helmond, A. The platformization of the web: Making web data platform ready. Soc. Media Soc. $2015,1$. [CrossRef]

61. Borghys, K.; Van der Graaf, S.; Walravens, N.; Van Compernelle, M. Governing the Quadruple Helix in the Age of 'Platforms'. Front. Sustain. Cities 2020. [CrossRef] 
62. Van Couvering, E. The political economy of new media revisited: Platformisation, mediatisation, and the politics of algorithms. Proceedings of the 50th Hawaii International Conference on System Sciences. 2017, pp. 1812-1819. Available online: http://hdl.handle.net/10125/41374 (accessed on 11 April 2020).

63. Zammit, A.; Kenna, T. (Eds.) Enhancing Places through Technology; Edições Universitárias Lusófonas: Lisbon, Portugal, 2017; pp. 1-287. ISBN 978-989-757-055-1. Available online: http://www.ceied.ulusofona.pt/pt/ download/publication-13-enhancing-places-through-technology/ (accessed on 27 May 2020).

64. Lupton, D.; Williamson, B. The datafied child: The dataveillance of children and implications for their rights. New Media Soc. 2017. [CrossRef]

65. Hintz, A.; Dencik, L.; Wahl-Jorgensen, K. Digital Citizenship and Surveillance Society: Introduction. Int. J. Commun. 2017, 11, 731-739.

66. Mascheroni, G. Researching datafied children as data citizens. J. Child. Media 2018, 12. [CrossRef]

67. Carpentier, N. Beyond the Ladder of Participation: An Analytical Toolkit for the Critical Analysis of Participatory Media Processes. Javn. Public 2016, 23, 70-88. [CrossRef]

68. Arnstein, S.R. A Ladder of Citizen Participation. J. Am. Plan. 1969, 35, 216-224. [CrossRef]

69. Faga, B. Designing Public Consencus-The Civic Theatre of Community Participation for Architects, Landscape Architects, Planner and Urban Designer; John Wiley \& Sons: Hoboken, NJ, USA, 2006.

70. Beale, N. Young People, Citizenship, Health and Participatory Research: Connections and Disjunctures in Field-Based Research. Acme: Int. E-J. Crit. Geogr. 2008, 7, 152-172.

71. Nir, T.; Perry-Hazan, L. The framed right to participate in municipal youth councils and its educational impact. Child. Youth Serv. Rev. 2016, 69, 174-183. [CrossRef]

72. Driskell, D. Creating Better Cities with Children and Youth; UNESCO: Paris, France, 2002.

73. Cowley, R.; Joss, S.; Dayot, Y. The smart city and its publics: Insights from across six UK cities. Urban Res. Pr. 2018, 11, 53-77. [CrossRef]

74. Shelton, T.; Lodato, T. Actually existing smart citizens: Expertise and (non)participation in the making of the smart city. City 2019, 23, 35-52. [CrossRef]

75. Cardullo, P.; Kitchin, R. Smart urbanism and smart citizenship: The neoliberal logic of 'citizen-focused' smart cities in Europe. Environ. Plan. C Politi Space 2018, 37, 813-830. [CrossRef]

76. Cardullo, P.; Kitchin, R.; Di Feliciantonio, C. Living labs and vacancy in the neoliberal city. Cities 2018, 73, 44-50. [CrossRef]

77. Van Dijck, J.; Poell, T.; De Waal, M. The Platform Society: Public Values in a Connective World; Oxford University Press: Oxford, UK, 2018.

78. Vanolo, A. Is there anybody out there? The place and role of citizens in tomorrow's smart cities. Futures 2016, 82, 26-36. [CrossRef]

79. Contract for the Web. Available online: https://contractfortheweb.org/ (accessed on 21 February 2020).

80. Holder, C.; Reidy, D. (Eds.) Human Rights: The Hard Questions; Cambridge University Press: Cambridge, UK, 2013.

81. Dworkin, R. Taking Rights Seriously; Harvard University Press: Cambridge, MA, USA, 1977.

82. Moyn, S. Reflections on 'The Last Utopia': A Conversation with Samuel Moyn. J. Hum. Rights Pract. 2011, 3 , 129-138. [CrossRef]

83. Livingstone, S.; Third, A. Children and young people's rights in the digital age: An emerging agenda. New Media Soc. 2017, 19, 657-670. [CrossRef]

84. Tsevreni, I. Children's social and spatial exclusion in the city: The need for an internal look. Int. J. Crit. Pedagog. 2015, 6, 149-168.

85. De Lange, M.; De Waal, M. Owning the city: New media and citizen engagement in urban design. First Monday. 2013, p. 18. Available online: http://firstmonday.org/ojs/index.php/fm/article/view/4954 (accessed on 11 April 2020).

86. Brenner, N.; Marcuse, P.; Mayer, M. (Eds.) Cities for People not for Profit: Critical Urban Theory and the Right to the City; Routledge: London, UK, 2012.

87. Shaw, J.; Graham, M. (Eds.) Our Digital Rights to the City; Meatspace Press: Oxford, UK, 2017.

88. Galdon, G. Technological Sovereignty? Democracy, Data and Governance in the Digital Era. CCCB Lab, 2017. Available online: http://lab.cccb.org/en/technological-sovereignty-democracy-data-and-governancein-the-digital-era/ (accessed on 5 April 2020). 
89. Morozov, E.; Bria, F. Rethinking Smart Cities: Democratizing Urban Technology; Rosa Luxemburg Stiftung: New York, NY, USA, 2018; Available online: http://www.rosalux-nyc.org/rethinking-the-smart-city/ (accessed on 13 April 2020).

90. Alderson, P. Children's rights and power. In 30 Years of Social Change; Jones, S., Ed.; Jessica Kingsley Publishers: London, UK, 2018; pp. 80-84.

91. Livingstone, S. Children's rights in the digital age. In The Routledge Companion to Media and Human Rights; Routledge: New York, NY, USA, 2017; pp. 104-113.

92. Macleod, C.M. Are Children's Rights Important. In Philosophical Foundations of Children's and Family Law; Brake, E., Ferguson, L., Eds.; Oxford University Press: Oxford, UK, 2018; pp. 191-208.

93. Sundhall, J. A Political Space for Children? The Age Order and Children's Right to Participation. Soc. Incl. 2017, 5, 164-171. [CrossRef]

94. Ferguson, L. Not merely rights for children but children's rights: The theory gap and the assumption of the importance of children's rights. Int. J. Child. Rights 2013, 21, 177-208. [CrossRef]

95. Derr, V.; Chawla, L.; Mintzer, M.; Cushing, D.F.; Van Vliet, W. A City for All Citizens: Integrating Children and Youth from Marginalized Populations into City Planning. Buildings 2013, 3, 482-505. [CrossRef]

96. Heimer, M.; Palme, J. Rethinking Child Policy Post-UN Convention on the Rights of the Child: Vulnerable Children's Welfare in Sweden. J. Soc. Policy 2016, 45, 435-452. [CrossRef]

97. Whitzman, C.; Worthington, M.; Mizrachi, D. The Journey and the Destination Matter: Child-Friendly Cities and Children's Right to the City. Built Environ. 2010, 36, 474-486. [CrossRef]

98. Malone, K. Children's rights and the crisis of rapid urbanization: Exploring the United Nations Post 2015 Sustainable Development Agenda and the potential role for UNICEF's Child Friendly Cities Initiative. Int. J. Child. Rights 2015, 23, 1-20.

99. Karsten, W.V.V. Child-Friendly Cities in a Globalizing World: Different Approaches and a Typology of Children's Roles. Child. Youth Environ. 2015, 25, 1-15. [CrossRef]

100. UNICEF. Child Friendly Cities and Communities Handbook; UNICEF: Geneva, Switzerland, 2018.

101. Broberg, A.; Kytta, M.; Fagerholm, N. Child-friendly urban structures: Bullerby revisited. J. Environ. Psychol. 2013, 35, 110-120. [CrossRef]

102. Sergeyeva, O.; Laktukhina, E. Child in "smart city": Social studies review of children's mobility. In Proceedings of the EGOSE '16, St.Petersburg, Russia, 22-23 November 2016. [CrossRef]

103. Boyd, D. It's Complicated: The Social Lives of Networked Teens; Yale University Press: New Haven, CT, USA, 2014.

104. Davies, C.; Coleman, J.; Livingstone, S. (Eds.) Digital Technologies in the Lives of Young People; Routledge: London, UK, 2014.

105. Nolas, S.-M.; Varvantakis, C. The Child's Gaze: Exhibition Catalogue. 2019. Available online: http: //research.gold.ac.uk/25583/ (accessed on 13 April 2020).

106. Varvantakis, C. 'Like the Palm of my Hand': Children and Public Space in Central Athens. LivingMaps Rev. 2018, p. 4. Available online: http://livingmaps.review/journal/index.php/LMR/article/view/99 (accessed on 3 February 2020).

107. Kitchin, R.; Dodge, M. Code/Space: Software and Everyday Life; MIT Press: Cambridge, MA, USA, 2011.

108. Sassen, S. Does the city has Speech. In Emergent Urbanism: Urban Planning $\mathcal{E}$ Design in Times of Structural and Systemic Change; Haas, T., Olsson, K., Eds.; Ashgate: Farnham, UK, 2014; pp. 133-140.

109. Breuer, J.; Walravens, N.; Ballon, P. Beyond defining the smart city: Meeting top-down and bottom-up approaches in the middle. J. Land Use Mobil. Environ. 2014, 7, 153-164.

110. Hatuka, T.; Rosen-Zvi, I.; Birnhack, M.; Toch, E.; Zur, H. The Political Premises of Contemporary Urban Concepts: The Global City, the Sustainable City, the Resilient City, the Creative City, and the Smart City. Plan. Theory Pract. 2018, 19, 160-179. [CrossRef]

111. De Lange, M.; De Waal, M. (Eds.) The Hackable City: Digital Media and Collaborative City-Making in the Network Society; Springer: Singapore, 2019.

112. De Waal, M.; Dignum, M. The citizen in the smart city. How the smart city could transform citizenship. It Inf. Technol. 2017, 59, 263-273. [CrossRef]

113. Anastasiu, I. Unpacking the smart city through the lens of the right to the city: A taxonomy as a way forward in participatory city-making. In The Hackable City: Digital Media and Collaborative City-Making in the Network Society; De Lange, M., De Waal, M., Eds.; Springer: Singapore, 2019; pp. 239-260. 
114. Hintz, A.; Brown, I. Enabling Digital Citizenship? The Reshaping of Surveillance Policy after Snowden. Int. J. Commun. 2017, 11, 782-801.

115. Waze for Cities. Available online: https://www.waze.com/ccp (accessed on 21 February 2020).

116. Toekomststraat. Available online: http://www.toekomststraat.be/ (accessed on 18 February 2020).

117. Wray, S. To Make Your City Smarter, Start with the Kids. 2018. Available online: https://www.smartcitiesworld. net/special-reports/special-reports/to-make-your-city-smarter-start-with-the-kids (accessed on 9 January 2020).

118. Children and the GDPR. Available online: https://ico.org.uk/for-organisations/guide-to-data-protection/ guide-to-the-general-data-protection-regulation-gdpr/children-and-the-gdpr/ (accessed on 22 January 2020).

119. Schrøder, K.C. Towards the 'Audiencization' of Mediatization Research? Audience Dynamics as Co-constitutive of Mediatization Processes. In Dynamics of Mediatization: Institutional Change and Everyday Transformations in a Digital Age; Driessens, O., Bolin, G., Hepp, A., Hjarvard, S., Eds.; Palgrave Macmillan: London, UK, 2017; pp. 85-116.

120. Augustin, S. Designing for Humans: The Essentials. Conscious Cities J. 2017, 2. [CrossRef]

121. Suchocka, M.; Maksymiuk, G.; Kimic, K.; Kołodyńska, N. Behaviour, expectations and preferences of 'digital natives' in regard to the design of urban public spaces. In Enhancing Places Through Technology; Zammit, A., Kenna, T., Eds.; Edições Universitárias Lusófonas: Lisbon, Portugal, 2017; pp. 167-180. ISBN 978-989-757-055-1. Available online: http://www.ceied.ulusofona.pt/pt/download/publication-13enhancing-places-through-technology/ (accessed on 27 May 2020).

122. Garau, C.; Annunziata, A. Smart City Governance and Children's Agency: An Assessment of the Green Infrastructure Impact on Children's Activities in Cagliari (Italy) with the Tool "Opportunities for Children in Urban Spaces (OCUS)". Sustainability 2019, 11, 4848. [CrossRef]

(C) 2020 by the author. Licensee MDPI, Basel, Switzerland. This article is an open access article distributed under the terms and conditions of the Creative Commons Attribution (CC BY) license (http://creativecommons.org/licenses/by/4.0/). 